спрямована на досягнення певних навичок, загалом вони згруповані навколо основної компетенцї: вміти описувати процедури інспекцій та оглядів на судні, їхні вимоги та документи. Частина А включае загальний огляд інспекцій, описи портового контролю, контролю держави прапора, внутрішніх і зовнішніх аудитів і вимог. Частина Б містить витяги з різних інспекційних документів, рекомендації для капітанів, звіти про проведені перевірки, які містять виявлені недоліки, чек-листи. Частина С спрямована на ознайомлення з видами оглядів, їх метою та періодичністю. Кожна тема зазначеної частини містить тексти-рапорти з сайту Chirp Maritime. Загахом модуль збагачений адаптованими автором кейсами, які є джерелом автентичної інформації для формування критичного мислення, інтеграції різноманітних мовних навичок та генерування власних ідей.

Ключові слова: модуль, суднові інспекції, морська англійська мова, магістр, студенти факультету судноводіння, викладання, частина, тема.

Дата надходження статті: 19.10.2021 p. Рецеензент: доктор педагогічних наук, доцент Рябуха I. М.

UDC 378.016:811.111

DOI https://doi.org/10.37915/pa.vi50.314

Sovach K. O. ,

orcid.org/0000-0002-8376-7623

\title{
SOME TIPS TO TEACHERS OF HIGHER EDUCATION AS FOR NON-PHILOLOGICAL STUDENTS GRAMMATICAL COMPETENCY FORMATION (CASE STUDY OF MODAL VERBS)
}

An important aspect of training students of a non-philological specialty is the formation of foreign language communicative competence. Successful development of the latter is impossible without the formation of all its basic components, one of which is grammatical competency as knowledge of grammatical elements of language and the ability to use them in communication, on the one hand, and connections and patterns established between grammatical phenomena and concepts they express, on the other hand.

The article highlights eight tips for teachers as for the formation and improvement of grammatical competency of students of non-philological specialties on the grammatical topic "Modal verbs" in classes of the subject "Foreign language (English)". The main focus is on the step-by-step recommendations of teaching modal verbs as speech units expressing the speaker's subjective attitude to what he is saying.

The following tips are outlined: analysis of the theoretical and practical content of the basic textbook, according to which the topic "Modal Verbs" is taught; establishing feedback through the involvement of students in clarifying the essence of modality in general; introduction of grammatical material through the definition of dominant modal verbs, semi-modal verbs and other verbs denoting modality; illustration of the easiest way to study modal verbs; outlining the typical mistakes that students often make while studying this topic (here the teacher also illustrates the key features of modal verbs); comparison of means expressing modality in Ukrainian and English with an emphasis on different shades of expression of duty or obligation; differentiation between modal verbs of low and high modality; focusing on the triad - modal verb, tense and time reference.

${ }^{*}$ C Sovach K. O.

U3 
जs ПЕДАГОГИНИЙ АЛЬМАНАХ. - 2021. - ВИПУСК 50

Us

Key words: student of non-philological specialty, foreign language communicative competence, grammatical competency, modal verb, modality, different shades of modality, typical mistakes, low and high modality.

The statement of the issue. The main task of vocational education is to prepare students for modern labor market. Graduates of Economic faculty of Kherson State Agrarian and Economic University must have high professional qualities. In addition to the process of globalization the importance of knowledge of foreign languages increases. Teaching foreign languages is currently relevant, since the content of education guides future specialists of economic specialties towards free development, creative initiative, independence, competitiveness, and sufficient mobility.

Actually the main method of teaching foreign languages is communicative method, and its main purpose is teaching speaking. Speaking is concerned to be extremely multidisciplinary and complex process: firstly, it performs the function means of communication; secondly, it is one of the types of human activity; thirdly, there is an utterance, as a result of the activity of speaking. And as an activity, and as a product, speaking has certain characteristics that serve as a guide in teaching, as they suggest what conditions need to be created for the development of speaking and, moreover, criteria for assessing learning outcomes. Speaking training is being implemented due to the formation of speech, or, in other words, communication skills. Any speech skills being conditions of speech ability and functioning at its basis, must have a system of qualities such as automation, stability, flexibility, consciousness, relative complexity, etc.

The concept of communicative competence was introduced by D. Hymes, who defined it as inherent human knowledge and skills of successful and effective communication [11, p.5]. Communicative competence is a multicomponent phenomenon including linguistic, speech, sociocultural, educational, strategic, discursive, cognitive, informative and pragmatic competencies, which, in the process of communication, should act out integrally.

When learning the grammatical aspect of communication, a special role is given to language competence as the ability to understand and produce unlimited number of linguistically correct sentences with the help of learned language signs and rules of their combination, to construct grammatically correct forms and syntactic constructions, and also to understand the semantic segments in the speech organized according to existing norms of the language, and use them in that way in which they are used by native speakers.

Teaching foreign languages to students of non-philological specialties always has its own specifics. This is primarily due to the number of hours provided by the curriculum for conducting practical classes, as well as to the characteristics of students and their level of English proficiency. In this regard, the problem related to the elimination of "school gaps" in knowledge of English grammar arises constantly. Such a correction is necessary, since it is impossible to introduce new vocabulary on the basis of unmastered grammatical material [2, p. 45].

J. Richards says "that the learners' mastery of speaking skill has become the main goal in learning English as a second language or foreign language. Moreover, he states that the learners will assess their success in language learning, especially how effective they use the language, by looking at how they have improved their speaking skill" [10, p. 110; 16, p. 19].

An indicator of the formation of language competence is the level of mastering grammatical and comparative analysis, expressed in the skill of highlighting certain aspects of the grammar studied and that of the native language; summarizing the basic units of language and using models when identifying the internal properties of these units; 
determining relations between grammatical forms; predicting the difficulties of using grammatical phenomena in foreign language speech.

It is well- known that the goal of training at the university is to expand the vocabulary from the field of professional communication, however, this activity will be successful if new words are learned on a good grammatical basis. When implementing a communicative goal in the process of oral or written communication, it is often necessary to use modal verbs, since they show the speaker's attitude to what is happening. In this regard, the study of the problem of teaching modal verbs becomes relevant and, moreover, the effectiveness of learning grammar material depends on the qualified approach of the teacher to the issue above.

The analysis of relevant research. In Ukrainian and foreign language teaching methodology as well as linguistics the study of modal verbs is presented by academic writings of S. Drachevych [1], R. Milrud, I. Maksimova [4], T. Savenko [5], J. Boyd, J. Thorne [7], A. Downing, P. Locke [9], and others. One of the major topics to be investigated in this field is modality as "linguistic devices that indicate the degree to which an observation is possible, probable, likely, certain, permitted, or prohibited" [15]. All other explanations and definitions of modality confirm the importance of mastering this category by students in general and modal verbs in particular. The matter of modality has been largely studied and many viable solutions have been found, for instance, various ways of modality manifestation: modal verbs alongside with lexico-modal auxiliary verbs (have to / have got to, be bound to, be supposed to, be going to, be likely to); semi-modal verbs (need, dare); the verbs (to allow, to beg, to command, to forbid, to guarantee, to guess, to promise, to suggest, to warn); the verbs pointing out imaginary events (to wonder, to wish) [9]. Among other ways of modality realization, we can distinguish such as modal adverbs (possibly, thankfully, certainly, obviously, hopefully, probably); modal adjectives (likely, possible, probable), modal nouns (possibility, chance, probability); introductory sentences (I believe, I guess). Recent papers focus on overcoming the problem of teaching modal verbs by proposing different schemes for their training $[1 ; 2 ; 5]$.

The purpose of the article is to describe some consequent steps how to develop the students' grammatical competency at English lessons within the discipline "Foreign Language (English)". We can apply our algorithm to solve this problem.

The body of the research. Tip 1. Before introducing the theoretical material as for modal verbs the teacher, to our mind, should scan the textbook the students are going to follow. In our case according to the academic programme "Foreign Language (English)" we use the textbook "Grammarway 2" by J. Dooley, V. Evans [8]. One unit (Unit 12) of the textbook is designed for the topic discussed. Having analyzed the unit we see the first section describes the meanings of may - might - could [8, p. 80]. The second part presents a passage of should - ought to - shall - will usage [8, p. 81]. Only after that the list of functions of modal verbs is given in table format [8, p. 82]. Some training exercises are posted on one page $[8$, p. 84]. As a conclusion there is a revision box [8, p. 85]. As we see the information is given mainly about core modal verbs. Nothing is said about semi-modal verbs and expressions denoting modality. To our mind the textbook presents too little information to develop the students' grammatical competency. That's why we recommend to work out more training exercises. To achieve this goal one need to consult and scan other English textbook as for the grammar material discussed.

Tip 2. Students are proposed to explain in their own words what modality is. If there are some difficulties the teacher may offer to feel the difference between some sentences, for example: I calculate and I can calculate, I may calculate, I must calculate. The students must realize that the sentence I calculate merely states the performance of the action by its doer. The other examples (I can calculate, I may calculate, I must calculate) show the degree of physical ability, 
certainty and obligation involved in the action. Thus, "a modal verb is a type of verb that is used to indicate modality - that is: likelihood, ability, permission, request, capacity, suggestions, order, obligation, or advice" [13]. M. Lassoff believes that "modality is the type of behavior, expression or way of life that belongs to a particular person or group of people" [13].

Tip 3. The teacher briefly introduces modal verbs by grouping them into key modal verbs (can, could, may, might, will, shall, would, should, must), semi-modals (dare, need, ought to, used to) and other verbs having modal meanings (have (got) to, be going, be able to).

Tip 4. One of the simplest ways of presenting this topic, in our opinion, is to point out the easiest way of learning modal verbs for students to remember their primary meanings. To illustrate this point of view we must focus our attention to the fact that modal verbs are often used to talk about abilities and possibilities or their absence. So, ability/inability and possibility/impossibility can be in the focus of students' attention: "Price is the most important factor but there are other factors also that can influence demand", "Exposure to uncertainty in economic value that cannot be marked-to-market" [6].

Tip 5. The teacher must fix the students' attention on some common mistakes with regard to modal verbs. Firstly, all modal verbs (ought to be the exception) follow the infinitive without particle -to or, in other words, there is any preposition after them: "Business risk is exposure to uncertainty in economic value that cannot be marked-to-market" [6]. Secondly, one cannot add any endings to the modal verbs, i.e. we can't say "Equilibrium is some balance that can occurs in a model, which can represents a prediction if the model has a real-world analogue" [6], in spite of balance being a third-person singular noun. Thirdly, we can't create any participles or past forms from modal verbs, it is incorrect to say or write "We musted do the calculations". Fourthly, modal verbs cannot stand together in one sentence, for example, "For multivariable functions, relative extreme points will cannot be visually identified on the edges of tables or contour graphs" [6]. Fifthly, if you want to form negative form of the modal verb, use the particle "not" after the modal verb: "The limits within which your housing and debt ratios must not fall are determined primarily by the size of the loan" [6], not "must don't fall".

Tip 6. Students should perceive that in their native language (Ukrainian) formally modal words manifest themselves in different ways: by adverbs (дійснo), pronouns (yсе), verbs (здається), particles (мабуть), adjectives (найдавніний) and nouns (поза сумнівом). It should be stated that in Ukrainian we use the verbs denoting the attitude of the speaker towards the object of the discussion in such ways as можу, повинен, слід зробити, but in English there is a slight difference between modal verbs denoting obligation: obligation due to circumstances (have to - "You have to pay back the loan" [6]), obligation that equals order (must "Thus, Private Mortgage Insurance (PMI) must be paid for lower equity (high LTV) loans to safeguard the lender from possible loan defaults" [6]), obligation as advice (should - "Extrapolation should always be viewed with caution" [6], obligation with a shade of moral duty (ought to - "When input values of a set of data are evenly spaced and the second differences of the output values are constant, the data ought to be modeled by a quadratic function" [6].

Tip 7. The teacher should differentiate between the modal verbs of low and high modality. Low modality points out less certainty, probability, importance, confidence, frequency, extent, obligation, intensity, or emphasis: could, may, might, would: "Sometimes, the absolute prices of goods may change but relative prices may remain constant", "For example, a mortgage might be defined as a 30-year fixed-rate loan at 7.625 percent, with an APR of 7.800 percent" [6]. High modality shows a high degree of these "attitudes": must, should, shall, has to: "Should interest rates fall during that period, you must honor the lock", "The amount of time you have to pay back the loan is the note's term" [6]. 
Tip 8. The teacher also must pay students' attention to such a triad as modal verbs, tense and time reference. It should be stated that we in most cases use modal verbs to discuss and illustrate future or possible present events. However, these verbs may not supposedly be like normal present or past tense verbs. But there are chief ways in which the tense of these modals goes on relevant. Past-tense Sequence: "The teacher said a continuous graph could be drawn without lifting the writing instrument from the page" [6]. Present-tense Sequence: "The teacher says a continuous graph can be drawn without lifting the writing instrument from the page" [6].

It should be noted that two English modal verbs must and ought to don't have any pasttense equivalents. It is important to highlight the fact that in Middle English these verbs were formed on the basis of other verbs past tenses. Nowadays they perform themselves as entirely present-tense verbs: "A society must decide what jobs will be done and who will do them" [3, p. 19]; "Just 12 years later, aggregate demand became a core concept in an introduction to economics written by Paul Samuelson that would in turn displace the certainties of Marshall's Principles, and would become the standard for what every aspiring economist ought to know" [14].

It is necessary to note that if we want to use must or ought to in a past-time context, we have to adherent to the alternative way of indicating past time - to use the perfect infinitive after these modal verbs: "The limits within which your housing and debt ratios must have fallen are determined primarily by the size of the loan" [6].

For improving non-philological students' grammatical competency, the teacher may use various training exercises as, for example, to fill in appropriate forms of the infinitive after modal verbs (Tip 8); to match the given meanings of speaker's attitudes with modal verbs themselves (Tip 6); to make own sentences expressing different meanings of modality (Tip 2); to differentiate modal verbs according to their high and low modality (Tip 7); to choose between modal verbs, semi-modal ones and expressions denoting modality (Tip 3); to present the story using modal verbs (Tip 1); to correct mistakes (Tip 5); to choose among the list of the meanings of modal verbs their primary meanings (Tip 4). In addition, students can be offered to find and present the video material within the matter discussed or to search the Internet and analyze videos posted on YouTube.

Conclusions. These findings provide additional information not about modal verbs themselves but some recommendations to teachers of higher educational establishments how to form and improve grammatical competency of non-philological specialties students. Importantly, our results provide evidence for further detailed development of exercises on the topic "Modal verbs" for students majoring in economics.

\section{Bibliography:}

1. Драчевич С. Практичний курс англійської мови: модальні дієслова та їх вживання в англійській мові. Дрогобич : Редакційно-видавничий відділ ДдПУ ім. І. Франка, 2015. 50 с.

2. Злобина Е. А., Злобина А. Н., Петрова Е. А. Обучение модальным глаголам в английском языке студентов неязыковых направлений. Advanced Science. Гуманитарные науки. 2017. № 2. C. $45-51$.

3. Мазур О., Совач К. Ангдійська для економістів=English for Economists: навчальний посібник для студентів закладів вищої освіти. Херсон : ОДДІ-ПДЮС. 2021. 232 с.

4. Мильруд Р. П., Максимова И. Р. Современные концептуальные принципы коммуникативного обучения иностранным языкам. Иностранные языки в школе. 2000. № 5. C. $17-22$.

5. Савенко Т. Розвиток граматичної компетенції вживання в усному і писемному мовленні модальних дієслів. Наукові записки. Серія: Філологічні науки. Кіровоград. ЦДПУ ім. В. Винниченка. 2018. Вип. 165. С. 552-557. 


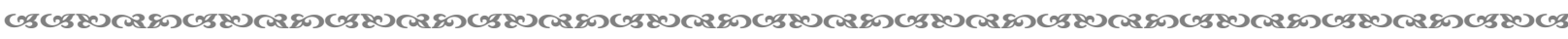
ПЕДАГОГІЧНИЙ АЛЬМАНАХ. - 2021. - ВИПУСК 50

Us

6. A Collection of Keywords and Phrases for Economics Decision Making. URL: https://home.ubalt.edu/ntsbarsh/business-stat/stat-data/KeywordsPhra.htm

7. Boyd J., Thorne J. The semantics of modal verbs. Journal of Linguistics. 2008. Volume 5. Issue 1. P. 57-74. DOI: https://doi.org/10.1017/S002222670000205X.

8. Dooley J., Evans V. Grammarway 2 with answers. Newbury : Express Publishing, 2015. 192 p.

9. Downing A., Locke P. A university course in English grammar. Routledge London, 2002. 610 c.

10. Fikron Moh. R. Grammatical Competence within L2 Communication: Language Production, Monitor Hypothesis, and Focus on Forms Instruction. PancaranPendidikan. 2017. Vol. 7. No. 1. P. 101-112. DOI: https://doi.org/10.25037/pancaran.v7i1.140.

11. Hymes D. On Communicative Competence. The Communicative Approach to Language Teaching. London, 1989. P. 5-27.

12. Identifying and using modality. Teaching strategies. URL: https://education.nsw.gov.au/teachingand-learning/student

13. Lassoff M. What are high modality words examples? GotThisNow. URL: https://gotthisnow.com/what-are-high-modality-words-examples

14. Looking forward to economics after CORE. The Economy. URL: https://www.core-econ.org/theeconomy/book/text/50-01-looking-forward.html

15. Nordquist R. Modality (Grammar and Semantics). URL: https://www.thoughtco.com/modalitygrammar-and-semantics-1691396

16. Richards J. C. Teaching Listening and Speaking. Cambridge : Cambridge University Press. URL: http://www.finchpark.com/courses/tkt/Unit 07/Richards-Teaching-Listening-Speaking.pdf

\section{References:}

1. Drachevich, S. (2015). Praktychnyi kurs anhliiskoi movy: modalni diieslova ta yikh vzhyvannia v anhliiskii movi [Practical English course: modal verbs and their use in English]. Drohobych: Redaktsiinovydavnychyi viddil DDPU im. I. Franka [in Ukrainian].

2. Zlobina, E. A., Zlobina, A. N., \& Petrova, E. A. (2017). Obuchenie modalnyim glagolam $\mathrm{v}$ angliyskom yazyike studentov neyazyikovyih napravleniy [Teaching modal verbs in English for non-linguistic students]. Advanced Science. Gumanitarnyie nauki, 2, 45-51 [in Russian].

3. Mazur, O., \& Sovach, K. (2021). Anhliiska dlia ekonomistiv [English for Economists]. Kherson: OLDIPLIUS [in English].

4. Milrud, R. P., \& Maksimova, I. R. (2000). Sovremennyie kontseptualnyie printsipyi kommunikativnogo obucheniya inostrannyim yazyikam [Modern conceptual principles of communicative teaching of foreign languages]. Inostrannyie yazyiki $v$ shkole, 5, 17-22 [in Russian].

5. Savenko, T. (2018). Rozvytok hramatychnoi kompetentsii vzhyvannia v usnomu i pysemnomu movlenni modalnykh diiesliv [Development of grammatical competency in the use of modal verbs in oral and written speech]. Naukovi zapysky. Seriia: Filolohichni nauky, 165, 552-557 [in Ukrainian].

6. A Collection of Keywords and Phrases for Economics Decision Making. Retrieved from https://home.ubalt.edu/ntsbarsh/business-stat/stat-data/KeywordsPhra.htm [in English].

7. Boyd, J., \& Thorne, J. (2008). The semantics of modal verbs. Journal of Linguistics, 5(1), 57-74. doi: https://doi.org/10.1017/S002222670000205X [in English].

8. Dooley, J., \& Evans, V. (2015). Grammarway 2 with answers. Newbury: Express Publishing [in English].

9. Downing, A., \& Locke, P. (2002). A university course in English grammar. Routledge London [in English].

10. Fikron Moh., R. (2017). Grammatical Competence within L2 Communication: Language Production, Monitor Hypothesis, and Focus on Forms Instruction. Pancaran Pendidikan, 7 (1), 101112. doi: https://doi.org/10.25037/pancaran.v7i1.140 [in English].

11. Hymes, D. (1989). On Communicative Competence. The Communicative Approach to Language Teaching, 5-27.

12. Identifying and using modality. Teaching strategies. Retrieved from https://education.nsw.gov.au/teaching-and-learning/student [in English].

13. Lassoff, M. (2021). What are high modality words examples? GotThisNow. Retrieved from https://gotthisnow.com/what-are-high-modality-words-examples [in English].

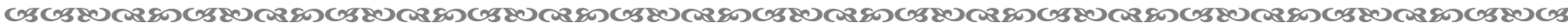
136 
14. Looking forward to economics after CORE. The Economy. Retrieved from https://www.coreecon.org/the-economy/book/text/50-01-looking-forward.html [in English].

15. Nordquist, R. (2021). Modality (Grammar and Semantics). Retrieved from https://www.thoughtco.com/modality-grammar-and-semantics-1691396 [in English].

16. Richards, J. C. (2021). Teaching Listening and Speaking. Retrieved from http://www.finchpark. com/courses/tkt/Unit 07/Richards-Teaching-Listening-Speaking.pdf [in English].

Совач К. О.,

\section{ДЕЯКІ ПОРАДИ ВИКИАДАЧАМ ЗАКДАДУ ВИЩОЇ ОСВІТИ ЩОДО ФОРМУВАННЯ ГРАМАТИЧНОЇ КОМПЕТЕНЦІЇ У СТУ ДЕНТІВ НЕФІЯОЯОГІЧНИХ СПЕЦІАЯЬНОСТЕЙ (НА МАТЕРІАЯІ ТЕМИ «МОДАЯЬНІ ДІЕСЯОВА»)}

Важливим аспектом підготовки здобувача нефілологічної спеціальності є формування іншомовної комунікативної компетентності. Успішний розвиток останньої неможливий без сформованості всіх їі базових компонентів, одним із яких постае граматична компетенція якзнання граматичних елементів мови та вміння ними користуватися в процесі спіккування, зодного боку, та зв'язки і закономірності, що встановлюються між граматичними феноменами та поняттяли, які вони виражають, з іншого боку.

У статті висвітлено вісім порад викладачам щодо формування та вдосконалення граматичної компетенції у студентів нефілологічних спеціальностей з граматичної теми «Модальні дієслова» на заняттялх з дисципліни «нноземна мова (англійська)». Основну увагу зосереджено на покроковій методиці навчання модальним дієсловам як мовленневим одиницям, що виражатоть суб'єктивне ставлення мовця до того, про щь він повідомляє.

Окреслюються такі поради: аналіз теоретико-практичного наповнення базового підручника, за яким викладається тема «Модальні дієслова»; встановлення зворотного зв'язку через залучення здобувачів до з'ясування сутності модальності загалом; введення граматичного матеріалу через визначення домінувальних модальних дієслів, напівмодальних дієслів та інших дієслів на позначення модальності; ілюстрація найлегшого способу вивчення модальних дієслів; окреслення типових помилок, які найчастіше роблять здобувачі під час вивчення цієё̈ теми (тут викладач також ілюструе ключові особливості модальних дієслів); порівняння засобів вираження модальності в украӥнській та англійській мовах з акцентом на різні відтінки вираження обов'язку чи зобов'язання; диференцігація між модальними дієсловами низької та високої модальності; фокусування уваги на тріаді - модальне дієслово, видо-часова форма дієслова та посилання на час.

Ключові слова: здобувач нефілологічної спеціальності, іншомовна комунікативна компетентність, граматична компетенцзія, модальне дієслово, модальність, різні відтінки модальності, типові помилки, низька та висока модальність.

Дата надходження статті: 29.10.2021 p. Рецензент: доктор педагогічних наук, доцент Яиула Т. В. 